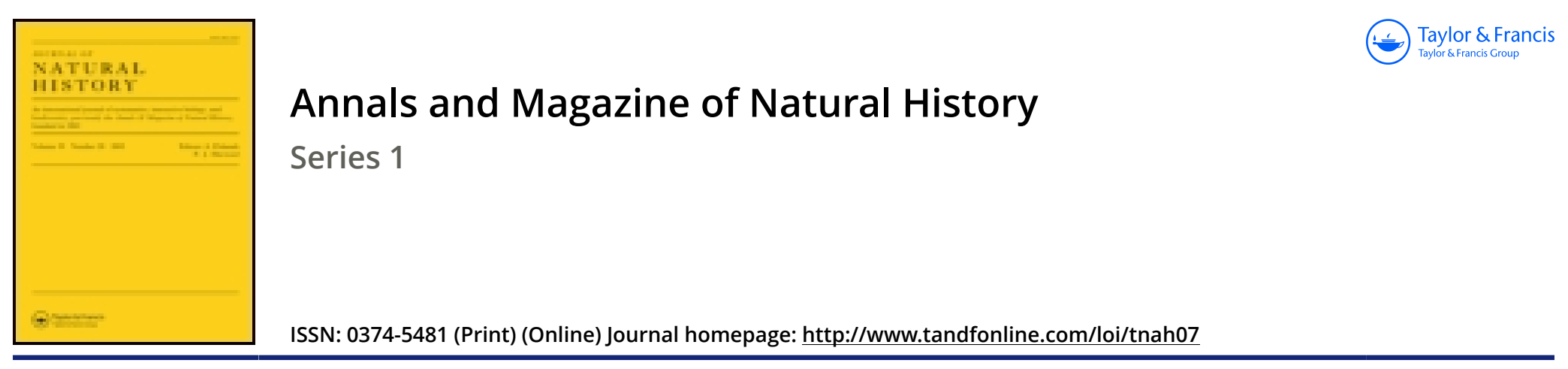

\title{
The gigantic Japanese salamander
}

\author{
J. E. Gray
}

To cite this article: J. E. Gray (1838) The gigantic Japanese salamander, Annals and Magazine of Natural History, 1:5, 413-413, DOI: 10.1080/00222933809512331

To link to this article: http://dx.doi.org/10.1080/00222933809512331

$$
\text { 曲 Published online: } 15 \text { Mar } 2010 .
$$

Submit your article to this journal

Ш Article views: 1

Q View related articles $\asymp$ 
tuated at the summit of the foot. M. d'Orbigny gives the following characters to the new genus which he establishes: "Animal fixed to the soil by a root taking the form of the solid bodies to which it is attached; from this root or base proceeds a foot or entire body, short, thick, hollow, containing the viscera, and opening into a mouth, which at the same time performs the functions of the anus, placed at the bottom of an irregular cavity, formed by the union of dense dichotomous arms, which are porous, exteriorly convex, and grooved interiorly, divided into numerous articulations, and longitudinally armed alternately with small conical very compressed branches."-Annal. Scien. Nat., Feb. 1837.

THE GIGANTIC JAPANESE SALAMANDER.

The attention of the continental naturalists appears to have been at length attracted by the fine gigantic salamander, which was discovered in Japan by Dr. Siebold, and which has been lying for several years in the yard of the Leyden Museum. Professor Van der Hoeven has lately given some detail of its anatomy, and has shown that it is as nearly allied in osteological character as it is in external appearance to the American genus Menopoma of Harlan, though his detail shows that Prince Charles Bonaparte was quite correct (when he exhibited the drawing of the specimens at the Zoological Society in the latter part of last year) in forming for it a new genus, which he proposed to call Sieboldia, after its discoverer. For according to the account of Van der Hoeven it has no lateral opening on the sides of the neck, which is so distinct in the Menopoma.-J.E. Gray.

\section{ZOOTOCA VIVIPARA.}

Desmarest, Daudin, and the other French naturalists are quite agreed as to this lizard, which is widely dispersed over Europe, being oviparous; and that the ova are deposited at the foot of walls, \&c. exposed to the sun. In Scotland the animal is ovo-viviparous, as I have repeatedly ascertained from the possession of specimens which have bred in my possession in 1827, 1828, and 1829. One of these, caught 19 th June 1829 , brought forth on the 27th July nine young in all. They were excluded inclosed in membranous sacs. The young were of a blackish brown colour when alive, and very active. For want of proper food they all died within a fortnight. The mother of this brood was fed with flies. After October she only crawled out of her hiding place in mild days and during sunshine. She was still alive at Christmas lying coiled up among the moss in the box in which she was kept. She died however some time during the severity of the winter.-J. Stork. 